University of Montana

ScholarWorks at University of Montana

Fall 2016

\title{
Client as Subject: Humanizing the Legal Curriculum
}

Eduardo R.C. Capulong

Alexander Blewett III School of Law at the University of Montana, eduardo.capulong@umontana.edu

Follow this and additional works at: https://scholarworks.umt.edu/faculty_lawreviews

Part of the Legal Education Commons, and the Legal Profession Commons Let us know how access to this document benefits you.

\section{Recommended Citation}

Capulong, Eduardo R.C., "Client as Subject: Humanizing the Legal Curriculum" (2016). Faculty Law Review Articles. 137.

https://scholarworks.umt.edu/faculty_lawreviews/137

This Article is brought to you for free and open access by the Faculty Publications at ScholarWorks at University of Montana. It has been accepted for inclusion in Faculty Law Review Articles by an authorized administrator of ScholarWorks at University of Montana. For more information, please contact scholarworks@mso.umt.edu. 


\title{
CLIENT AS SUBJECT: HUMANIZING THE LEGAL CURRICULUM
}

\author{
EduARdo R.C. CAPUlONG*
}

Clients are notoriously absent in the legal curriculum. And even in clinical instruction, we undertake, at best, an eclectic study of the client as subject. In this essay, the author examines the treatment of clients, in particular subordinated clients, in legal study and proposes organizing disparate strands of practice and scholarship into a distinct field of client studies - thereby humanizing the otherwise dehumanized study of law.

In an essay written four years after the publication of Rebellious Lawyering, Jerry López recalled sitting on a political lawyering panel at Harvard Law School and contemplating Charles Ogletree's remarks from the floor. "[W]e are forgetting the most important element," Professor Ogletree admonished. "[T]he client."

We keep thinking that we can solve these problems ... that we have all the ideas. And as you look around the room we [do] have all the [professional] expertise, the [professional experience], and the [professional] knowledge. But we don't have the clients. ${ }^{1}$

Unfortunately, the same is true of most of legal education: we don't have clients. Professor López's enduring contribution-Rebellious Lawyering is only one of many-is his insistence that clients are central to lawyering: the need to work collaboratively with them, root our work in their communities, and engage them authentically as human beings. As lawyers, we can be as skilled, devoted, and intrepid as we want. But without understanding, knowing how to work with, and finding common cause with our clients—as individuals, organizations, coalitions, communities, and social movements-and without attending to the political, social, economic, and historical circumstances in which we, together, find ourselves, we do our clients a disservice and accomplish nothing long-term.

This conviction is axiomatic in clinical legal education. Elliott

* Professor of Law, University of Montana Alexander Blewett III School of Law. I would like to thank Rosanne Balasabas and Taylor Thompson for their research assistance; Andrew King-Ries, Cathay Smith, Jonathon Byington, Anthony Johnstone, and Hillary Wandler for commenting on a previous draft of this essay; and my Rebellious Lawyering symposium co-presenters, Wendy Bach, Jeena Shah, Brian Gilmore, and Dara Fisher Page for their inspiring work.

1 Gerald P. López, An Aversion to Clients: Loving Humanity and Hating Human Beings, 31 Harv. C.R. - C.L. L. Rev. 315, 315 (1996). 
Milstein has observed that client-centered lawyering is "perhaps [our] ideological core."2 Yet even in the clinical canon, we undertake an eclectic study of the client at best. We spend much of our time as clinicians scrutinizing the lawyer-client relationship, but I know of no curricular approach that begins with a systematic, interdisciplinary study of clients as human beings. As Professor López lamented in Rebellious Lawyering,

at some level, we understood our problems with legal education to be deeper than our daily complaints. We realized that we were not just unhappy but in many ways unchallenged. Unchallenged by a place that had no idea about, and apparently little interest in, how to design its curriculum to systematically expose students to the complex lives of people like those with whom I had grown up. Unchallenged by a place that had no idea about, and apparently little interest in, how to draw on interdisciplinary knowledge that bears on both understanding and doing something to fight social, political, economic, and legal marginalization. Unchallenged by a place that had no idea about, and apparently interest in, how to enrich its faculty, its curriculum, its scholarship, and its communal life with more than just a token woman or person of color. ${ }^{3}$

In this essay, I suggest that we create a distinct field of academic inquiry: clients, in particular subordinated clients. Rising to Professor López's challenge, I propose that we organize the disparate strands of practice and scholarship in this area and develop a theoretical framework by which to study them. ${ }^{4}$ I attempt a modest step in that direction here. After summarizing the current conception and treatment of clients in the legal curriculum, I harness and reconceive various strands of literature and weave them into one curricular model for client studies. We are well-familiar with the ways in which most people are denied access to the legal system, less so with the ways in which that marginalization begins in law school. Outside of clinical instruction, law students deal rarely, if at all, with actual clients. The study of law is dehumanized-literally. I argue that we ought to align legal education with human need and teach law and lawyering not from the surreptitious, purportedly objective, perspective of legal doctrine nor simply from the professional perspective of the lawyer, but from the basic interests of actual, subordinated human beings. Instead of deforming human reality to suit the requirements of a legal

2 Elliott S. Milstein, Clinical Legal Education in the United States: In-House Clinics, Externships, and Simulations, 51 J. Legal Educ. 375, 378 (2001).

3 Gerald P. López, Rebellious Lawyering: One Chicano's Vision of Progressive Law Practice 4-5 (1992) [hereinafter "Rebellious Lawyering"].

4 I confine my discussion to the study of subordinated clients but believe that client studies can and should extend to the study of clients writ large. 
status quo or conceiving of clients purely as professionals, we ought to humanize legal study and practice by starting with our clients' needs, sensitizing our students to them, and insisting that the legal system comply.

\section{Clients in the Legal Curriculum}

Human beings are, of course, legal actors. To the extent that legal actors are clients (or potential clients), therefore, and coupled with the actual clients of clinics and field placements, it can be said that client studies are already, unavoidably part of the legal curriculum. On one end of the legal curricular spectrum is the constructed, cardboard client of the first-year doctrinal class, on the other the actual clients of clinics and field placements. In between and beyond are the simulated clients of legal research and writing, lawyering, student competition, and other simulation and experiential courses; the intersectional clients of critical theory; the embodied clients of law and psychology, neuroscience, and bodily studies; and the sociological clients of socio-legal studies. ${ }^{5}$ As I argue below, while extensive and overlapping, these discrete renditions are, by and large, disconnected, and, as such, are limited in their portrayals of the legal client.

\section{The Constructed, 'Cardboard' Client of the Traditional Doctrinal Course}

The clients encountered by the vast majority of law students are constructed: abstract figures stripped of human semblance. Encountering prospective clients from the perspective of institutions far removed from ordinary human existence-appellate courts-law students conceive a particular abstraction of the human juridical subject. Here, human identity and circumstance are defined by legal doctrine and formal legal institutions. ${ }^{6}$ In doctrinal courses, we are legal actors engaged in criminal or tortious conduct (Criminal Law and Torts); we bargain freely and autonomously (Contracts); we are creditors or debtors (Property); we possess standing to sue (Civil Procedure); we enjoy inherent rights and suffer immutable characteristics (Constitutional Law). We are criminal defendants, personal injury plaintiffs, business owners, landlords, tenants, husbands, wives, par-

5 I am sensitive to Muneer Ahmad's observation that "client" is not an identity, Muneer I. Ahmad, Interpreting Communities: Lawyering Across Language Difference, 54 UCLA L. REv. 999, 1078 (2007), but believe, nonetheless, in the creation of this distinct field of inquiry.

6 Ann Shalleck, Constructions of the Client Within Legal Education, 45 STAN. L. Rev. 1731, 1737 (1993) [hereinafter "Shalleck"] ("While the clients are situated outside of the legal realm, their identities are created and their experiences given meaning only within the existing terms of legal discourse."). 
ents, immigrants, etc.-in doctrinal terms, legal categories. In the traditional legal curriculum, observes Sol Picciotto, "[t]he basic legal category is the legal subject as the bearer of rights and duties." 7

William Simon has observed that there have been three conceptions of "man" in legal study: "Economic Man"-the "rational, egoistic, and materialistic" being associated with the constitutional doctrines of substantive due process and prominent from the late 19th century to the 1930s; "Sociological Man," a being associated with the legal realists and whose fundamental disposition is towards altruism; and "Psychological Man," whose foremost claim is to the "whole person" and whose goal is to achieve "a largely internal satisfaction, a 'sense of well-being,' . . . substantially independent of material factors or social relations." "Cardboard clients," Ann Shalleck has called them: autonomous individuals who seek only to maximize their wealth and freedom ${ }^{9}$ and whose essences boil down to these underlying motivations. Generally speaking, as far as legal doctrine is concerned, it does not matter whether you are male or female, black or white, gay or straight. Indeed, these realities are interchangeable in hypothetical classroom discussion. Traditional legal education individualizes the legal actor and, as Professor Shalleck observes, simultaneously strips clients of individual identity and gives them new identities and understandings necessitated by legal doctrine-a utilitarian undertaking designed to justify doctrinal development. ${ }^{10}$ The "certainty" of this process, she observes further, "is in direct contradiction to the open acceptance of ambiguity that characterizes evaluation of the same court's statements about the law."11

By force of circumstance, these new identities and understandings have had to accommodate assorted realities of the human condition. We no longer assume rationality in all contexts, for example, as emotional disability and duress are common human afflictions; we also recognize emotional harm as legally compensable. Equally-perhaps more-significant, the struggles of the poor, oppressed, and exploited have forced reconceptions of the legal actor. Even though we often

7 Sol Picciotto, The Theory of the State, Class Struggle and the Rule of Law, in MARXISM AND LAw 175 (Piers Bierne \& Richard Quinney eds., 1982).

8 William H. Simon, Homo Psychologicus: Notes on a New Legal Formalism, 32 Stan. L. Rev. 487, 492 (1980) [hereinafter "Simon"] (internal citation omitted). Psychological Man, argues Professor Simon, is centrally concerned with a "community of two," which is hostile to critical thinking and a materialist understanding. Critiquing this latest iteration of the cardboard client, Professor Simon argues for "political man"-or the construction of the client as a political actor.

9 Shalleck, supra note 6; see also Katherine R. Kruse, Beyond Cardboard Clients in Legal Ethics, 23 Geo. J. Legal Ethics 103 (2010).

10 Shalleck, supra note 6, at 1733.

11 Shalleck, supra note 6, at 1734. 
continue to assume an autonomous, rational, gains- and freedom-maximizing (not to mention, straight, white, middle-class, male) legal subject and object we are not so entirely limited. Thanks to the movements for racial, sexual, and gender equality; labor, welfare, immigrants', and disability rights; and others, our doctrinal conception of the client has been rendered diverse-theoretically at least. As opposed to one cardboard client, today we have many of them: equal protection plaintiffs, public benefits recipients, criminal defendants, and so on-a diversity, to be sure, but one-dimensional diversities in the law's understanding of their humanity nonetheless. Presuming formal equality, Lucille Jewel observes, the "core language" of legal reasoning "privileges technical form and levels of legal authority over social contexts and moral issues ... and tends to situate legal actors equally and erase and ignore social differences." 12

\section{The Simulated Client of Legal Research and Writing, Lawyering, Student Competition, and Other Experiential Courses}

In contrast to the constructed, cardboard client of the doctrinal course, legal research and writing, lawyering, student competition, and other experiential courses place students in-role as attorneys and develop the dramatis personae involved in client representation. ${ }^{13}$ Many of us create these exercises in extended fashion, imbuing them with realistic detail. Case simulation is essential pedagogical practice, increasingly occupying a greater role in legal education given the ABA's new experiential requirements. ${ }^{14}$ Here, students encounter simulated clients, composite characters possessing four essential features. First, they are, of course, fictional, an artifact that can both dramatize but also delimit the breadth and depth of human nature. Second, because simulations are designed to relate to pre-existing doctrinal and practical frameworks, simulated clients tend to be bereft of "extraneous" or legally irrelevant features and circumstances. That is, simulations tend to ascribe to clients the very "identities and understandings" necessitated by legal doctrine, as noted by Professor Shalleck. ${ }^{15}$ Third and relatedly, because it is impossible to simulate social circumstances fully and dynamically, simulated clients are bounded and are replete

12 Lucille A. Jewel, Bourdieu and American Legal Education: How Law Schools Reproduce Social Stratification and Class Hierarchy, 56 Buff. L. REv. 1155, 1196 n. 226 (2008).

13 See, e.g., Peggy Cooper Davis \& James Webb, Learning from Dramatized Outcomes, 38 Wm. Mitchell L. Rev. 1146 (2012).

14 ABA Standard 303(a)(3) at http://www.americanbar.org/content/dam/aba/publica tions/misc/legal_education/Standards/2015_2016_chapter_3.authcheckdam.pdf (last visited July 5, 2016).

15 Shalleck, supra note 6, at 1733. 
with individual, not social, detail. Simulated clients tend to be individual, not social, actors. Finally, simulated clients are standardized for pedagogical and assessment purposes. New York Law School, for example, aims for its actors "to assume the same profile, to know the same facts, and to respond appropriately to student questions and techniques so that the experience of each student is as close as possible to that of all other students." 16 Ironically, therefore, a client's individuality also tends to be excised in simulated settings. As with the cardboard client of the traditional doctrinal course, students' understanding of the simulated client is utilitarian, fragmentary, static, and decontextualized - that is, stripped of the very human realities in need of legal attention and recognition.

\section{The Actual Clients of Clinics and Field Placements ${ }^{17}$}

Clinical and field placement courses have been the primary correctives to these fictitious understandings. Occupying the opposite end of today's common legal curriculum, clinics and externships expose students to actual clients and the myriad complexities that attend each and every representation. Here, we find real human beings: Mrs. G., ${ }^{18}$ Josephine V., ${ }^{19}$ Boston Chinatown activists, ${ }^{20}$ immigrant workers, ${ }^{21}$ the movements for Black Lives ${ }^{22}$ and marriage equality, ${ }^{23}$ among countless others. Storytelling has been the principal literary device through which clinicians (and other legal scholars) have explored the human condition, Indeed, Rebellious Lawyering is a prime example of this genre. In the clinical canon we find story upon story of actual clients. As Binny Miller has observed, clinicians have written:

stories about actual clients seeking a wide range of public benefits, ranging from clients fighting to receive food stamps for their foster families to clients seeking milk and diapers for their infants to a

16 See Lawrence M. Grosberg, Standardized Clients: A Possible Improvement for the Bar Exam, 20 GA. ST. U. L. Rev. 841, 859-60 (2004).

17 Although distinct, I include in this category public interest law practice, curricula, and scholarship, as there is substantial overlap between them and clinical education.

18 Lucie E. White, Subordination, Rhetorical Survival Skills, and Sunday Shoes: Notes on the Hearing of Mrs. G., 38 Buff. L. Rev. 1 (1990) [hereinafter "White"].

19 Anthony V. Alfieri, Speaking Out of Turn: The Story of Josephine V., 4 Geo. J. Legal ETHics 619 (1991).

20 Zenobia Lai, Andrew Leong, \& Chi Chi Wu, The Lessons of the Parcel C Struggle: Reflections on Community Lawyering, 6 UCLA Asian PAC. Am. L.J. 1 (2000).

21 Sameer M. Ashar, Public Interest Lawyers and Resistance Movements, 95 CAL. L. REV. 1879 (2007).

22 Amna A. Akbar, Law's Exposure: The Movement and the Legal Academy, $65 \mathrm{~J}$. Legal Edu. 352 (2015).

23 Scott L. Cummings \& Douglas NeJaime, Lawyering for Marriage Equality, 57 UCLA L. REv. 1235 (2010). 
toddler suffering from sicklecell anemia struggling to participate in a state-sponsored nutrition program. Other clients face claims that they have received more public benefits than they are entitled to. [Clinicians have written] about clients charged with criminal offenses, including assault and battery, driving under the influence of alcohol, disorderly conduct, and resisting arrest. Some of the clients are homeless. Others seek civil rights: prisoners challenging prison disciplinary procedures as unconstitutional and African-Americans fighting for voting rights on a par with whites. There is an endless variety of stories. ${ }^{24}$

We tell these stories for a variety of instructional ends, among them to teach respect or about paternalism, ${ }^{25}$ autonomy, ${ }^{26}$ complexity, ${ }^{27}$ empathy, ${ }^{28}$ reconstructive case theory, ${ }^{29}$ and aging and competence. ${ }^{30}$ In the process, given the client-centered core of clinical pedagogy, we invariably have had to study clients in their countless guises and in their "full context-culturally, politically and economically." 31 It is no accident, for example, that clinicians have been pioneers in law and psychology ${ }^{32}$ and law and organizing. ${ }^{33}$ Characterizing clinical studies of clients, in other words, is an interdisciplinary perspective that draws from the fields of law, psychology, neuroscience, bodily studies, critical theory, sociology, anthropology, political science, and economics, among a host of other disciplines. And given that the vast majority of our clientele is subordinated, these studies constitute, in particular, a canon grounded in human plight and struggle.

24 Binny Miller, Telling Stories About Cases and Clients: The Ethics of Narrative, 14 Geo. J. Legal Ethics 1, 15 (2000) (internal citations omitted) [hereinafter "Miller"].

25 Mark Spiegel, The Case of Mrs. Jones Revisited: Paternalism and Autonomy in Lawyer-Client Counseling, 1997 BYU L. REv. 307 (1997).

26 Id.; William H. Simon, Lawyer Advice and Client Autonomy: Mrs. Jones's Case, 50 MD. L. ReV. 213 (1991).

27 See, e.g., Leslie G. Espinoza, Legal Narratives, Therapeutic Narratives: The Invisibility and Omnipresence of Race and Gender, 95 Mich. L. Rev. 901 (1997).

28 Philip M. Genty, Clients Don't Take Sabbaticals: The Indispensable In-House Clinic and The Teaching of Empathy, 7 CLIN. L. Rev. 273 (2000); Cynthia M. Dennis, Expanding Students' View of the Dilemmas of Womanhood and Motherhood, 46 How. L.J. 269 (2003).

29 Binny Miller, Give Them Back Their Lives: Recognizing Client Narrative in Case Theory, 93 Мich. L. Rev. 485 (1994); Christopher P. Gilkerson, Poverty Law Narratives: The Critical Practice and Theory of Receiving and Translating Client Stories, 43 Hastings L. J. 861 (1992).

30 Robert Rubinson, Construction of Client Competence and Theories of Practice, 31 Ariz. ST. L.J. 121 (1999).

31 Michelle S. Jacobs, People from the Footnotes: The Missing Element in Client-Centered Counseling, 27 Golden Gate U. L. Rev. 345, 352 (1997).

32 See, e.g., Marjorie A. Silver, Love, Hate and Other Emotional Interference in the Lawyer/Client Relationship, 6 Clinical L. Rev. 259 (1999) [hereinafter "Silver"].

33 See, e.g., Scott L. Cummings and Ingrid V. Eagly, A Critical Reflection on Law and Organizing, 48 UCLA L. REV. 443 (2001). 
But broad and deep as the clinical canon is, I know of no attempt to integrate these (and other) studies into a systematic curricular whole. And whereas I would argue for basing the study of the client outside of the lawyer-client relationship, ${ }^{34}$ most approaches remain anchored in that professional perspective. Rebellious Lawyering is, of course, Professor López's critique of one such perspective: the elitist practice of what he called "regnant" lawyering. ${ }^{35}$ Since then, Kate Kruse has elaborated on the "plural values" of client-centered lawyering and various approaches that approximate those that I advocate for here. ${ }^{36}$

Despite the deficiencies and eclecticism of client studies in doctrinal, experiential, and clinical courses, there are, beyond them, numerous scholarly inquiries that fill in gaps. These inquiries also present an incomplete rendition of the client; and together, they form a disorganized, perplexing whole. In the following sections, I note the emergence of these various inquiries and, in the final section, propose a reweaving and development of this entire body of work that might create a more complete and coherent curriculum of the legal client.

\section{The Intersectional Clients of Critical Theory}

Beyond the common curriculum, critical theory has served as the principal jurisprudential current challenging the formalist, utilitarian notion of the legal subject. Insisting on the subjectivity of the legal actor, critical legal studies, critical race theory, feminist jurisprudence, and queer jurisprudence point to differences based on class, race, sex, gender, and sexual orientation. Describing the multidimensionality and intersectionality of human identity and subordination, these theoretical currents endow the cardboard client with complexity and diversity. And adopting the legal realist approach to law, politics, economics, and society, they question formalist legal agency, challenge assumptions about client autonomy and equality, and advance political and moral claims about law and the legal system.

Given our common zeitgeist, ${ }^{37}$ many clinicians use critical theory to deepen students' understanding of actual clients. In two clinics at American University, for example, Margaret Johnson and her col-

34 I realize the seeming contradiction between calling for the study of the "client", which presupposes a professional relationship, and calling for that study to be based outside of that relationship. What I mean is the study of the client beyond his, her, or their identities as such. See also supra note 5 on "client" as identity.

35 Rebellious Lawyering, supra note 3.

36 Katherine R. Kruse, Fortress in the Sand: The Plural Values of Client-Centered Representation, 12 CLIN. L. Rev. 369 (2006).

37 Minna J. Kotkin, Creating True Believers: Putting Macro Theory into Practice, 5 Clin. L. Rev. 95, 99 (1998). 
leagues used feminist theory to teach students about difference, introduce them to a systemic critique of the legal system, and discuss the role of power, privilege, and agency. ${ }^{38}$ Similarly, Robert Williams developed a "critical race practice" clinic focused on Indian law at the University of Arizona. ${ }^{39}$ Intentional or not, many clinicians ineluctably draw on critical theory to examine the realities of race, class, sex, gender, and sexual orientation with our students.

\section{The Embodied Client of Law, Psychology, Neuroscience, and the Body}

The fields of law and psychology, neuroscience, and the body, too, increasingly have informed and supplemented these clinical and critical investigations. Here, we find the "embodied" client. For example, Marjorie Silver was among the first to draw on psychological literature to explain client behavior. ${ }^{40}$ More recently, in their book, "Psychology for Lawyers," Jennifer Robbennolt and Jean Sternlight draw on Professor Silver's and others' work to understand human behavior in negotiation, litigation, and decision-making. ${ }^{41}$ Similarly, Carwina Weng calls upon the use of cognitive and social psychology to teach students cultural self-awareness ${ }^{42}$ and Richard Birke has examined the practical applications of neuroscience in settlement. ${ }^{43}$ Spawning movements for "therapeutic jurisprudence" and "affective lawyering," this literature has deep ramifications for such basic legal precepts as the reason-emotion duality, rationality, the reliability of eyewitness testimony, the epistemology of fact, and the nature of persuasion. Joshua Greene and Jonathan Cohen argue that recent advances in neuroscience "will probably have a transformative effect on the law . . . by transforming people's moral intuitions about free will and responsibility." ${ }_{4}$ Professors Greene and Cohen foresee "a shift

38 Margaret E. Johnson, An Experiment in Integrating Critical Theory and Clinical Education, 13 Am. U. J. Gender Soc. Pol'y \& L. 161 (2005). See also Phyllis Goldfarb, Beyond Cut Flowers: Developing a Clinical Perspective on Critical Legal Theory, 43 HasTINGs L.J. 717 (1992); Phyllis Goldfarb, A Theory-Practice Spiral: The Ethics of Feminism and Clinical Education, 75 Minn. L. Rev. 1599 (1991).

39 Robert A. Williams, Vampires Anonymous and Critical Race Practice, 95 Mich. L. REV. 741 (1997).

40 See Silver, supra note 32.

41 Jennifer K. Robbennolt \& Jean R. Sternlight, Psychology for Lawyers: Understanding the Human Factors in Negotiation, Litigation, and Decision MAKING (2012).

42 Carwina Weng, Multicultural Lawyering: Teaching Psychology to Develop Cultural Self-Awareness, 11 Clinical L. Rev. 369 (2005).

43 Richard Birke, Neuroscience and Settlement: An Examination of Scientific Innovations and Practical Applications, 25 OHio St. J. on Disp. Resol. 477 (2010).

44 Joshua Greene \& Jonathan Cohen, For the Law, Neuroscience Changes Nothing and Everything, 359 Philosophical Transactions 1775 (2004) ["Greene \& Cohen"]. 
away from punishment aimed at retribution in favour of a more progressive, consequentialist approach to the criminal law."45 Finally, emerging scholarship in how the law is embodied-in Michel de Certeau's words, "inscribed on bodies" 46 _promises to deepen even further our understanding of the client as a human organism.

\section{The Sociological Client of Socio-Legal Studies}

Finally, the broad field of socio-legal studies offers other interdisciplinary scholarship on the legal actor. Here, we find the sociological client. Drawing from the fields of sociology, anthropology, political science, economics, psychology, and others, law and society scholars study clients in these various contexts and provide insight informed by empirical and ethnographic data. These "macrostudies", as Professor Miller calls them, ${ }^{47}$ include inquiries into the legal consciousness of the welfare poor, defendants' satisfaction in and views of the criminal justice system, ${ }^{48}$ small-claims plaintiffs, traffic and misdemeanor defendants, and housing court tenants. ${ }^{49}$ I would include in this category Matthew Desmond's ethnography of poor families facing eviction, Michelle Alexander's study of mass incarceration, Barbara Ehrenreich's undercover investigation of the lives of the working poor, Jonathan Kozol's research on black and white public school students,${ }^{50}$ and other such studies of the subordinated.

\section{Systematizing the Study of the Legal Client}

We clearly have a wealth of knowledge about legal clients. But much of this knowledge resides outside the common legal curriculum. Separately, they are incomplete, and together, they are disorganized. Unlike the encyclopedic coherence of legal doctrine or the clinical focus on the lawyer-client relationship, law students draw at best on an eclectic know-how of the human condition. Even those of us commit-

\footnotetext{
45 Id.

46 Julian Webb, The Body in (E)motion: Thinking though Embodiment in Legal Education, in Affect and Legal Education: Emotion in Learning and Teaching the LAW 214 (Paul Maharg \& Caroline Maughan eds., 2011); see also Gary Watt, Dress, Law And the Naked Truth: A Cultural Study of Fashion and Form (2013) and Ruthann Robson, Dressing Constitutionally: Hierarchy, Sexuality, \& Democracy From Our Hairstyles to Our Shoes (2013).

47 See Miller, supra note 24, at 17.

48 Id. at 12 n. 62.

49 Id.

50 Jonathan Kozol, Savage Inequalities: Children in America's Schools (2012); Barbara Ehrenreich, Nickeled and Dimed: (ON) Not Getting By in America (2d ed., 2011); Michelle Alexander, The New Jim Crow: Mass Incarceration in the Age of Colorblindness (2012); Matthew Desmond, Evicted: Poverty and Profit in the American City (2016).
} 
ted to rebellious lawyering, I imagine, struggle (as I do) to piece together a curriculum that honors the client-centered core of our pedagogy. Given our dual professional commitment, as lawyers and clinicians, to represent and teach about our clients, the systematization of client studies is long overdue. If we are to collaborate with our clients, root our work in their communities, and engage them authentically as human beings; if we truly want to understand, know how to work with, and find common cause with them as individuals, organizations, coalitions, communities, and social movements and attend to the political, social, economic, and historical circumstances in which we, together, find ourselves, then I suggest we knit together the various pedagogical and intellectual strands I summarize above into a systematic whole. Such a project, I sketch in this section, might organize the literature and study the client in six dimensions: as human organisms, as legal actors, as subordinated class members, as social actors, as individual selves, and as political agents.

\section{Client as Human Organism}

We ought to begin with the human organism. Humans are not the rational, gains-maximizing actor of case-method lore. Nor for that matter simply "sociological," "psychological," or "political," as described by Professor Simon. ${ }^{51}$ We are, to the contrary, embodied beings predisposed to think, feel, and act in complex, contradictory, often irrational and self-destructive, ways. As mentioned, legal scholars have drawn from the fields of psychology, neuroscience, and bodily studies in order to better understand human makeup and behavior and better relate with clients. Indeed, some of these scholars draw on such studies to call for the practice of law as a healing profession. ${ }^{52}$ We ought to continue to look to this work to provide the basis for our conception of the legal subject and object. Students need to understand, for example, that we access reality not so much through our senses, as is commonly believed, but through our biases, which has profound implications for the creation of "fact". They need to understand the transhistorical and transcultural nature of storytelling and the way in which narrative creates "fact" and therefore is key to persuasive legal argument. ${ }^{53}$ Students also need to understand basic psychodynamics in order to interview and counsel effectively, as well as

\footnotetext{
51 Simon, supra note 8, at 492.

52 See, e.g., Linda Mills, On the Other Side of Silence: Affective Lawyering for Inmate Abuse, 81 Cornell L. Rev. 1225 (1996).

53 Jerome Bruner \& Anthony G. Amsterdam, Minding the Law 111 (2002); Anthony Amsterdam, Peggy Cooper Davis \& Aderson Francois, NYU LawYering Program Readings (2003).
} 
practice cultural self-awareness, as Professor Weng argues. Just as fundamentally, we need to do away with the reason-emotion duality at the root of legal analysis and acknowledge the fallability and suggestibility of human memory.

By the same token, we ought to continue to draw on the neurosciences to reexamine such basic legal precepts as autonomy and choice. Discussing criminal culpability, for example, Joshua Greene and Jonathan Cohen argue that while legal doctrine can accommodate recent neuroscientific findings because the law makes no assumptions about the neural basis of behavior, neuroscience will nonetheless change the law "by undermining the intuitive, libertarian conceptions of free will on which retributivism depends." 54 Arguing that "neuroscience will challenge and ultimately reshape our intuitive sense(s) of justice" and "change the way people think about human action and criminal responsibility," Professors Greene and Cohen observe:

Free will as we ordinarily understand it is an illusion generated by our cognitive architecture. Retributivist notions of criminal responsibility ultimately depend on this illusion, and, if we are lucky, they will give way to consequentialist ones, thus radically transforming our approach to criminal justice. At this time, the law deals firmly but mercifully with individuals whose behaviour is obviously the product of forces that are ultimately beyond their control. Some day, the law may treat all convicted criminals this way. That is, humanely. ${ }^{55}$

In this day and age, any curriculum of legal study must include the basics of human biological, psychological, and neurological makeup. This is all the more important given the criteria by which we assess the successful law student. As George Critchlow observed of law school applicants:

While their cognitive skills may enable them to perform well in first-year law courses, applicants may lack maturity and emotional intelligence. They may, for example, lack an ability to tolerate difference, to recognize different problem-solving styles, to communicate effectively with a range of diverse people, to help identify realistic goals and strategies, to persuade, to be ethical and avoid the untoward temptations associated with money and power. ${ }^{56}$

54 See Greene \& Cohen, supra note 44, at 1783.

55 Id. at 1784.

56 George Critchlow, Beyond Elitism: Legal Education for the Public Good, 46 U. ToLEDo L. REv. 311 (2014) (internal citations omitted) [hereinafter Critchlow]; see also Elizabeth Chambliss, It's Not About Us: Beyond the Job Market Critique of U.S. Law Schools, 26 Geo. J. Legal Ethics 423 (2013) (book review). 
\begin{tabular}{lllll}
\hline |ljciprod01 productn|N|NYC123-1\NYC109.txt & unknown & Seq: 13 & 21-OCT-16 & $7: 19$ \\
\hline
\end{tabular}

Fall 2016]

Humanizing the Legal Curriculum

49

\section{Client as Legal Actor}

Client as legal actor is the role most familiar to law students. We need to continue to examine how legal doctrine and formal legal institutions define the client, of course. But we must also supplement this understanding with human and legal realities. That is, we should reclaim and add to cases details shorn from appellate opinions and the Socratic method and reinject those realities into them. For example, students need to know that, in addition to being a passenger of the Long Island Railroad, Helen Palsgraf was a cleaning woman whose litigation costs were triple her annual income. ${ }^{57}$ They need to know about how tenants are routinely silenced in housing court, 58 or how defendants experience the criminal justice system. ${ }^{59}$ Here, we ought to supplement doctrinal and simulation materials with human attributes and draw from empirical studies of clients' experiences with the legal system. Doing so would undermine the utilitarian understanding of clients as caricatures justifying doctrinal development.

\section{Client as Subordinated Class Member}

Foremost among such realities is our clients' experiences of exploitation and oppression. Clinical clients are subordinated by class, race, sex, gender, sexual orientation, and so on. As Professors Greene and Cohen note, "there is no 'him' independent of these [contexts]." 60 It's therefore essential that we study the subordination borne out of these specific oppressions. Law students need to understand the specificity of wage labor, the history of slavery and Jim Crow, the struggle for LGBTQ equality, among other histories, and the modern-day iterations of these struggles in, say, union drives, the Movement for Black Lives, and marriage equality. Here, we should continue to draw on critical theory and socio-legal studies to deepen our understanding of the subordinated client.

\section{Client as Social Actor}

The subordination our clients experience from the legal system, class society, and various oppressions-and the opportunities for liberation made possible by them-form but part of our clients' social

\footnotetext{
57 William L. Prosser, Palsgraf, Revisited, 52 Mich. L. Rev. 1 (1953).

58 See Barbara Bezdek, Silence in the Court: Participation and Subordination of Poor Tenants' Voices in Legal Process, 20 Hofstra L. Rev. 533 (1992).

59 See, e.g., Jonathan D. Casper, Having Their Day in Court: Defendant Evaluations of the Fairness of Their Treatment, 12 LAw \& Soc'y REv. 237 (1978).

60 See Greene \& Cohen, supra note 44, at 1778-79 ("was it him, or was it his upbringing? Was it him, or was it his genes? Was it him, or was it his circumstances? Was it him, or was it his brain?").
} 
world. There are myriad other social dimensions in which our clients also exist: political, religious, cultural, subcultural. Such social experiences manifest themselves in associations, networks, communities, institutions, and other social structures that also require examination if we are to fully understand our clients. Here, too, socio-legal studies provide a rich source of information.

\section{Clients as Individual Self}

From these bases-clients' biological makeup and social experiences-are formed our clients' conception of themselves. Similar as our respective makeup and circumstances may be, we are all also, at the same time, unique individuals and regard ourselves as such. We are born with different genes, for example, some of us more prone to certain diseases and behavior over others. Our genetic expression is, in turn, modified by our life experiences, ${ }^{61}$ and so on. Professors Greene and Cohen describe this as our "our first-person sense of ourselves,"62 expressed in the "thick" narratives of clients in clinical scholarship. ${ }^{63}$ This subjective sense of self is what our client-centered ethos honors and it is what allows for human agency. Here, a curriculum of client studies would draw on and extend the many narratives in the clinical tradition.

\section{Client as Political Agent}

Finally, Rebellious Lawyering, like other progressive tracts before and after it, is premised on the conviction that our clients-not us lawyers-are the agents of social change. What has cohered as "law and organizing" literature is essentially the study of the client as political agent. Related to but distinct from narratives of individual clients, studies of client organizations, coalitions, mobilizations, and social movements are key to the extent that they situate clients in collective political struggle. These are profiles of political consciousness and resistance. They provide glimpses of alternative social visions and inspire hope in the possibility of fundamental social change.

\section{Towards Client Studies}

I teach a Law and Social Justice seminar. In a paper, one of my students wrote:

Unfortunately, "[t]he first thing I lost in law school was the reason

\footnotetext{
61 See, e.g., David Eagleman, The Brain on Trial, The Atlantic, 2011.

62 See Greene \& Cohen, supra note 44, at 1783 (citing Daniel Wegner, The Illusion of Conscious Will, (MIT Press 2002) ("our first-person sense of ourselves" as having free will is an "illusion")).

63 See e.g., White, supra note 18.
} 
that I came." Law school has a tendency to sterilize the issues that are discussed in the classroom and read about in cases. The human element is removed from the equation, and all that is left in most instances is a cold, almost mechanical application of law to facts. This is generally not a problem when the discussion turns to the proper conduct of a corporation or government entity, but then, discussions of corporations and government entities are not why I went to law school. To remove the humanity from the people who are the subject of discussion is to maintain the status quo in the law school classroom, in the profession, and in society. Dehumanizing the struggles that people face makes it easy to create and justify sweeping rules of law, in the name of order and judicial efficiency, that apply evenhandedly to everyone. Yet, what we sacrifice in our pursuit to effectively handle an ever-increasing number of problems is fairness and justice for the powerless, because "[w] hat is legal is often not just. And what is just is often not at all legal." I am not suggesting that there should a different rule for everyone dependent upon one's bargaining power. That would be both impossible in practice and unwise in theory because the lawyers are not the motors of social change. What is suggested is merely that we not forget that law and legal education is first and foremost about solving human problems. ${ }^{64}$

Chief Justice John Roberts visited the University of Montana a few years ago. In a forum with law students, one asked him whether, in deciding cases and writing opinions, he considered how they would affect people "on the ground." The Chief Justice said no. While I suspect he intended to convey the impartiality with which he and his colleagues decided cases, some, perhaps many, of us read a stunning insensitivity to the way he thought about the high Court's responsiveness to-and power over-ordinary human lives. Such an insensitivity constitutes the ideological and structural underpinning of the prevailing-and unjust-socio-economic order. And it is an insensitivity that results, at least in part, from a legal education unmoored from the human condition. Educating and socializing lawyers without actual clients perverts the function of law, misshapes students' professional identities, squanders pro bono opportunities, and perpetuates many of the ills besetting our students and profession. ${ }^{65}$

The "new epistemology of practice," argues the Carnegie Report, "start[s] from engagement rather than a claim of detached objectiv-

64 Taken from a final paper written by a student in my Law \& Social Justice seminar (internal citation omitted) (paper on file with author).

65 See, e.g., Peggy Cooper Davis et al., Making Law Students Healthy, Skillful, and Wise, 56 NYLS REv. 487, 488 (2011) (suggesting that "collaborative experience and wellstructured critical analysis of lawyers' work are necessary, not only to professional excellence, but also to students' ability to contain stress sufficiently to manage the complex mental work of learning and using the law"). 
ity."66 A critique of the Langdellian case method, the argument is for the integration of theory and practice, and the decentering of appellate courts as the primary subject of academic inquiry. Practical engagement, in turn, means clients. The multifaceted engagement of clients not only enriches legal education but, in the end, also transforms it-from elite "training for hierarchy" 67 to "law in the service of human needs." 68 I invite colleagues to join me in creating and organizing an academic field of inquiry and curricular program dedicated to the study of the legal client.

66 William M. Sullivan, Anne Colby, Judith Welch Wegner, Lloyd Bond, \& Lee S. Shulman, Educating Lawyers: Preparation for the Profession of Law 9 (2007).

67 Duncan Kennedy, Legal Education as Training for Hierarchy, in D. KAIRYs, ED., The Politics of Law (1998); see also Critchlow, supra note 46.

68 This is the motto of my alma mater, CUNY School of Law, available at http:// www.law.cuny.edu/admissions/cunylaw-brochure.pdf. 